\title{
リニア型超音波内視鏡による噴門癌の口側浸潤診断の検討
}

千葉大学医学部第 2 外科

$\begin{array}{lllllll}\text { 有馬美和子 } & \text { 神津 } & \text { 照雄 } & \text { 荻野 } & \text { 幸伸 } & \text { 大島 } & \text { 郁也 } \\ \text { 古市庄二郎 } & \text { 山崎 } & \text { 義和 } & \text { 円山 正博 } & \text { 今野 } & \text { 秀次 } \\ \text { 山田 } & \text { 英夫 } & \text { 坂口 } & \text { 文秋 } & \text { 小野田昌一 } & \text { 山本 } & \text { 義一 } \\ \text { 磯野 可一 } & & & & & & \end{array}$

\section{A STUDY ON THE DIAGNOSIS FOR THE ORAL INVASION OF THE CARDIAC CANCER BY THE ELECTRONIC LINEAR ARRAY ENDOSCOPIC ULTRASONOGRAPHY}

\author{
Miwako ARIMA, Teruo KOUZU, Yukinobu OGINO, \\ Ikuya OHSHIMA, Shojiro FURUICHI, Yoshikazu YAMAZAKI, \\ Masahiro MARUYAMA, Hideji KONNO, Hideo YAMADA, \\ Fumiaki SAKAGUCHI, Syoichi ONODA, Yoshikazu YAMAMOTO \\ and Kaichi ISONO \\ Second Department of Surgery, School of Medicine, Chiba University
}

\begin{abstract}
リニフ型超音波内視鏡（EUS）では食道から噴門部の縦軸方向の画像がえられることを用いて，下 部食道胃境界領域の画像について検討した. EUS 上, hyperechoicな sm 層が肥厚，明瞭化する点を 食道胃粘膜接合部の目安にでさること, 胃壁と大動脈との間に描出される hypoechoic な横隔膜筋脚 の口側先端を食道姴孔部と同定できることを明らかにした。これを応用して，噴門癌の口側漫潤診断 を試みた。 術前 EUS で腫瘍口側と食道裂孔部との位置関係が描出でき, から標本 echo とその組織学 的対比の可能であった上部胃癌14例について検討した。術前 EUS で癌口側端が食道裂孔部を越えて 描出された症例は，開胸術式を必要とした，上部胃癌の診断に際しては従来の $\mathrm{x}$ 線，内視鏡所見から だけではなく，EUSから見た癌口側端と食道裂孔部との位置関係からも術式を検討すべきと考えられ
\end{abstract} た.

索引用語：リニア型超音波内視鏡, 食道胃粘膜接合部, 噴門癌口側浸潤, 胃癌食道浸潤

\section{1. はじめに}

超音波内視鏡（endoscopic ultrasonography：以下 EUS）は，膵疾患診断を目的として開発されたが，消 化管, とくに胃・食道疾患の診断に導入され, 消化管 壁の層構造の同定法から始まり, 胃癌・食道癌の深達 度診断の検討子行われてきた(1) 价. 癌深達度診断にお けるEUS の有用性は広く認められるところであり， 最近では転移リンパ節診断に対する研究も行わ れ(5)6)，質的診断にせまろうとしている.

$<1988$ 年 4 月 13 日受理 $>$ 別刷請求先：有馬美和子 厂260 千葉市春日 $2-15-16$
われわれる，1981年 6 月より東芝・町田社製リニア 電子走査式 EUS を使用し，上部消化管疾患に打ける 有用性を検討してきた。現在では胃癌・食道癌の深達 度診断, 転移リンパ節診断, また, 治療効果判定を目 的に, ルーチン検查として行っている.

リニア型EUSでは, 食道から噴門部の絽軸方向の 画像が得られることが特徵であり, 今回この特性を生 かして下部食道・噴門境界領域の画像について検討し た. 消化管の層構造の変化から食道胃粘膜接合部(esophago-gastric junction：以後 EGJ)が同定できること を明らかにし，また，新たに食道裂孔部(以後 hiatus) の位置をEUS 画像上明らかにした。 
この同定法を胃癌, とくに噴門癌の口側浸潤診断に 応用し，若干の知見を得たので報告する。

\section{2. 装置}

使用した超音波内視鏡は, 東芝・町田社製リ二>電 子走査式超音波内視鏡(周波数7.5MHz) で, その画像 表示には東芝メディカル社製 SAL-90A を用いた。

標本の水浸下 echo を行ら際には, 周波数 $7.5 \mathrm{MHz}$ の術中超音波探触子も使用した。

\section{3. 食道胃粘膜接合部と食道裂孔部の同定}

1) 食道胃粘膜接合部の同定法

現在使用している周波数 $7.5 \mathrm{MHz}$ の超音波内視鏡 では消化管壁, 特に胃壁は 5 層から 7 層に描出される。 食道壁は胃壁に比べ薄く描出され, 食道胃境界領域で 層構造に变化が認められることは, 臨床例で認識され ていた事実であった. そこで, 切除標本を用いて，EGJ 付近の層構造の変化について検討した。

食道癌で切除された直後の標本を固定板に固定し, 水槽内に標本を沈め, 正常な EGJ の水浸下 echoを 行った.

図 1A は肉眼的 EGJの粘膜面上に針を置いたるの で, 図 1B は針を除いて層構造を観察したるのである. EGJを境にして胃側では第 3 層の sm 層が肥厚し明瞭 となっている．また，第 4 層の $\mathrm{pm}$ 層も厚くなってい る. 図 1C は同部位の組織像で, EGJ を境にして胃側で は $\mathrm{sm}$ 層, pm 層の肥厚が認められ, echo 像と対応する ものであった。

症例によって層構造の変化には差があり, EGJを境 にして sm 層が有意に厚くなるもの, pm 層が厚くなる もの, 両層とも厚くなるものとが認められた。

2）食道裂孔部の同定法

噴門部では背側に薄い筋層から成る右または左の横 隔膜筋脚が，腹部食道を取り巻くように立ち上がり， hiatusを形成している7)。リニア型 EUS は噴門部に対 し縦軸方向の画像が得られるため，この横隔膜筋脚の 立ち上がりから口側の消失部を描出することが可能で ある。

超音波内視鏡を噴門部に挿入し, 胃液, 空気を吸引 後, 先端バルーンをふくらをせ, down angleをかけて プローブを胃後壁に密着させると, 腹部大動脈と消化 管壁の間に薄い hypoechoic layer を描出することが できる。この筋層は横隔膜筋脚と同定できる。

横隔膜筋脚は口側で三角形となり消失するが，この 消失部位を，横隔膜筋脚が横隔膜に移行する部，すな わち hiatus と同定している(図 2A 星印)。これより口
図 1 正常例の食道胃粘膜接合部の水浸下 echo 像と その組織像

A

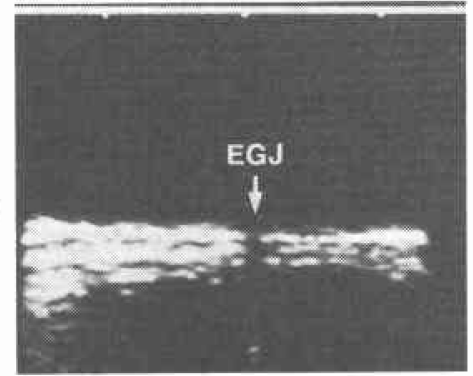

B

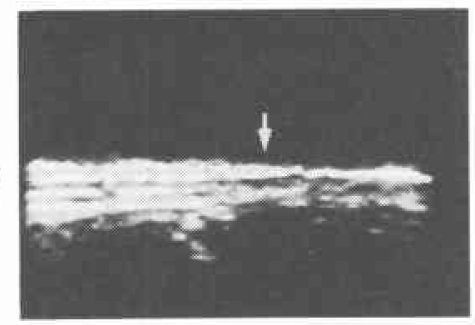

C

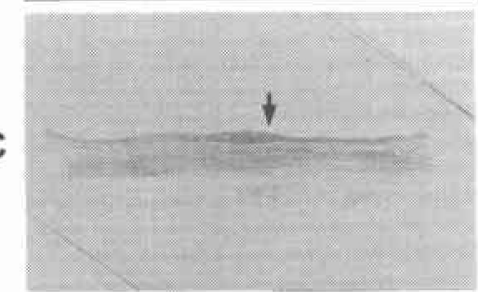

側が胸腔内と考えている。

3）食道胃粘膜接合部之食道裂孔部の関係

実際の EUS 像を呈示し, hiatus と EGJ との関係を 示す.

図 2A は正常の噴門部の EUS 像で, 消化管壁 と aorta との間に三角形の hypoechoic な横隔膜筋脚を 認める，脚の先端である hiatus（星印）の $1.5 \mathrm{~cm}$ 肛門 側を境に, 消化管壁は全体に肥厚し $\mathrm{sm}$ 層, $\mathrm{pm}$ 層が明 瞭に描出されて和り，EGJが hiatus 下 $1.5 \mathrm{~cm}$ に存在 している像である。

図 2Bでは，EGJ (三角印) は hiatus (星印) 直下ま で挙上しているが，正常範囲の像である.

図 2Cでは EGJ (三角印) は hiatus（星印）を越えて $1 \mathrm{~cm}$ 程胸腔内に入り込んで㧊り, hiatus hernia の像で ある.この症例は X 線像扔よび内視鏡検査でも hiatus hernia が確認されており，EUS 像は sliding hernia を おこした像と一致していた。

\section{4. 胃癌口側漫潤診断への応用}

胃癌口側浸潤獄断に, 以上述べた EGJ と hiatus の 


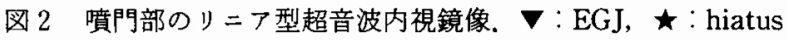

A

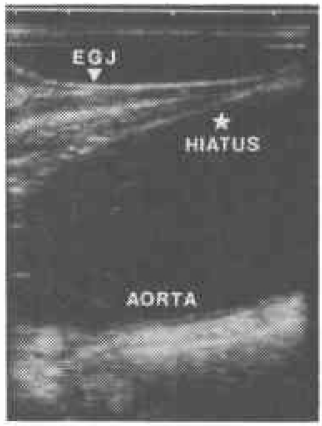

NORMAL
$\mathbf{B}$

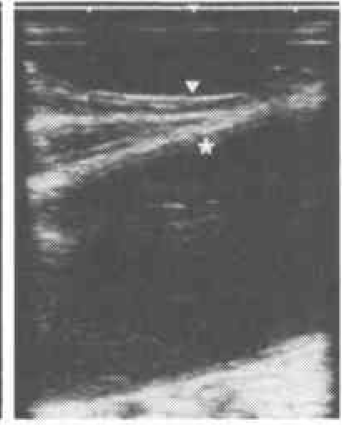

NORMAL
C

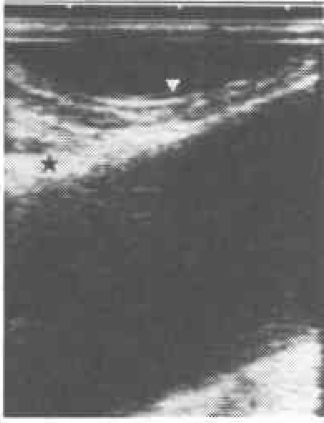

HIATUS HERNIA
同定法を応用した。

1）症例拉よび方法

胃癌，特に噴門癌，また，その食道浸潤例で，口側 浸潤境界の診断が問題となった症例を取り上げた。

術前EUS で癌后と hiatus の位置関係が確認でき， かつ癌口側端の形態について，標本 echoおよび組織 学的にも対比可能であった14例について検討した。

まず, 術前EUSでは癌口側の形態について険討し, また, 癌口側端と EGJ, hiatus との位置関係を描出乙 た. 同時に, 従来行ってきた癌深達度診断, 綎隔内, 腹腔内リンパ節転移診断も行った。

切除標本では切除直後の標本に対し水浸下 echoを 行い, 癌口側端の形態について検討した。

癌口側端の H.E. 染色による病理組織標本を作成 し, EUS 像, 標本 echo 像と比較, 検討した。 病理組織学的 owを計測した。

2) 成績

今回検討した14例の術前 EUS 像に括ける癌口側端 と hiatus の位置関係について検討した。

a）癌口側端が hiatus を越觉なかった例

術前 EUS で癌口側端が hiatusを越えていなかった 症例は 7 例であった。これら 7 例の EUS 像を, hiatus

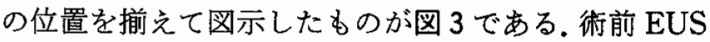
における hiatus と腫瘍口側端までの距離を下段に細 矢印で示し，EGJが確認できた場合は太棒でその位置 を示した。ささらに，術前 EUS 像と標本 echo 像, 組織 像を比較し，組織学的癌先進部を太矢印で示した。

EUS 画像上, 癌口側端は hiatus 下 $1 \sim 2.5 \mathrm{~cm}$ の範囲 に描出された. EGJは 4 例に描出可能であった.

7 例はいずれも開腹操作のみで切除可能であり, 病
図 3 噴門癌口側の術前 EUS 像一癌口側端が hiatus を越えない例一

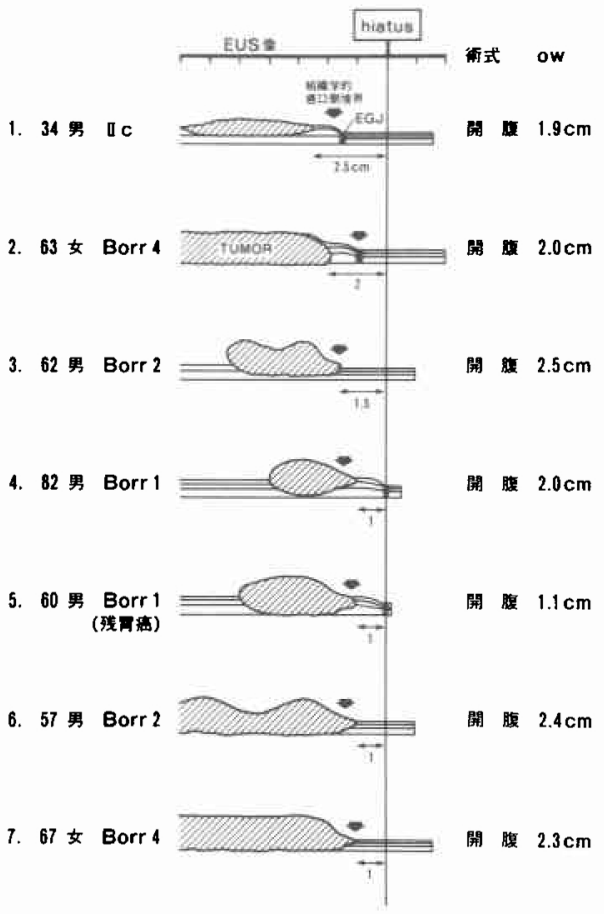

理組織学的にも ow は1.1 2.5cm をもって切除され ていた。

症例 1：(図 3-No. 3の症例）

62歳男性で, 典型的な Borrmann 2 型噴門癌の症例 である. X 線では小弯側, EGJ 直下に Borr. 2型胃癌を 認めた(図 4 左)。内視鏡では食道側よりの見招ろしで 約 $1 / 3$ 周に渡り EGJ に一致して口側の周堤を認め（図 
4 右上)，胃内で反転すると cardia に Borr. 2型胃癌を 認めた（図 4 右下）.

図 5 は術前 EUS 像であるが, A は腫場肛門側で sm 層の断裂を伴う境界明瞭な tumorであった. B は腫瘍 中央部で，pm層までおよぶ low echo mass として描 出され, 深達度 $\mathrm{pm}$ と診断した。C は腫瘍口側を描出し たものである. EGJ は不明瞭であり，腫場口䝶端を三 角印で示した. hiatus は腫痬口側端より口側 $1.5 \mathrm{~cm} に$ 描出された。

手術は経腹的に胃全摘術が施行された，図 6 はその 切除標本であるが，噴門部の $4 \times 3 \mathrm{~cm} の$ Borr. 2 型胃癌 で，肉眼的に $1 \mathrm{~cm}$ 食道浸潤を認めた。

図 7 上は切除標本の腫汮口側の水浸下 echo 像, 下 はその組織像である，三角印が腫瘍先進部であり，組

因 4 一症例 1一左：Borr. 2型噴門癌の X 線像, 右 上：内視鏡像, 食道側上りの見招ろ乙像, 右下：内 視鏡像, 胃内反転像
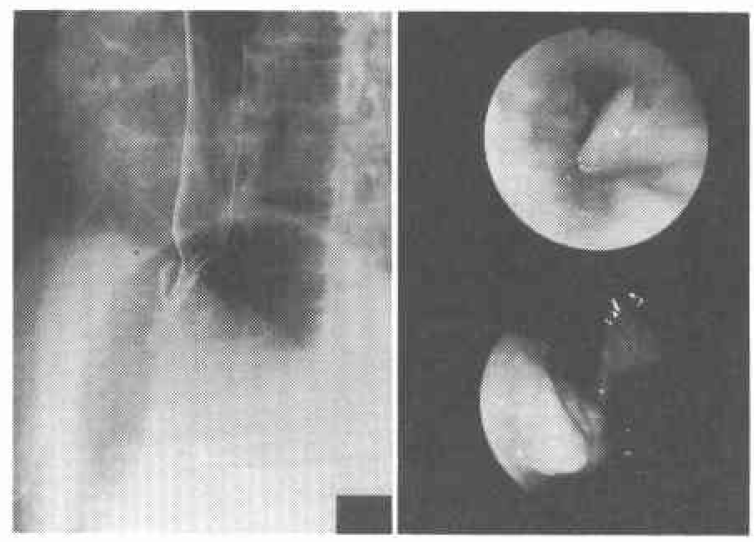

織学的には $0.5 \mathrm{~cm}$ 食道へ浸潤して括り, 深達度は $\mathrm{pm}$, ow $2.5 \mathrm{~cm}$ であった.

症例 2：（図 3-No. 2 の症例）

63歳女性で, MCA 領域に拈よぶ Borr. 4型胃癌である が，口側浸潤境界が問題になった症例である。 X 線像 では EGJ 下 $4 \mathrm{~cm}$ まで壁の硬化と伸展不良が認められ た(図 8 左).内視鏡では全周性の硬化と色調の変化が EGJ下2cm までおよんでいた（図8右）。

図 9 に術前 EUS 像を示すが，A は胃体部の腫瘍中 央部で, 此較的層構造を保ちながら, 全層の低 echo 化，肥厚が認められた，肝，膵と腫場は近接しながら る可動性が保たれており，S2と診断した。Bは腫瘍口 側を描出したもので，矢印に示した EGJ下 $1 \mathrm{~cm} の 三$ 角印の部玉で全層の壁肥厚がおよんでいた。 また， EUS 上 EGJ は hiatus 下 $1 \mathrm{~cm}$ に位置していた。

手術は経腹的に食道を $2 \mathrm{~cm}$ 含めた胃全摘術が行わ れた。

図10A は切除標本の腫瘍口側の水浸下 echo 像であ る. 矢印で示した肉眼的 EGJを境に肛門側では第 3 層, 第 4 層は肥厚, 明瞭化し, EUS 上でも EGJ と同定 できる。この EGJ下 $1 \mathrm{~cm}$ (三角印) まで全体に低 echo 化した肥厚面がおよんでおり，腫瘍の浸潤と考えられ， 術前EUS と一致した像が得られた。図10B はその組 織像で，三角印の部をで全層性に癌細胞を認めた。し かし, microscopic には約 $1 \mathrm{~cm}$ 口側の矢印で示した EGJ まで浆膜面をはって癌浸潤が認められた。深達度

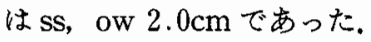

b）癌口側端が hiatusを越支ていた例

一方, 術前 EUS で癌口側端が hiatus を越えていた 例は 7 例であった。 7 例について，同様に hiatusを揃

図 5 一症例 1 一術前 EUS 像.
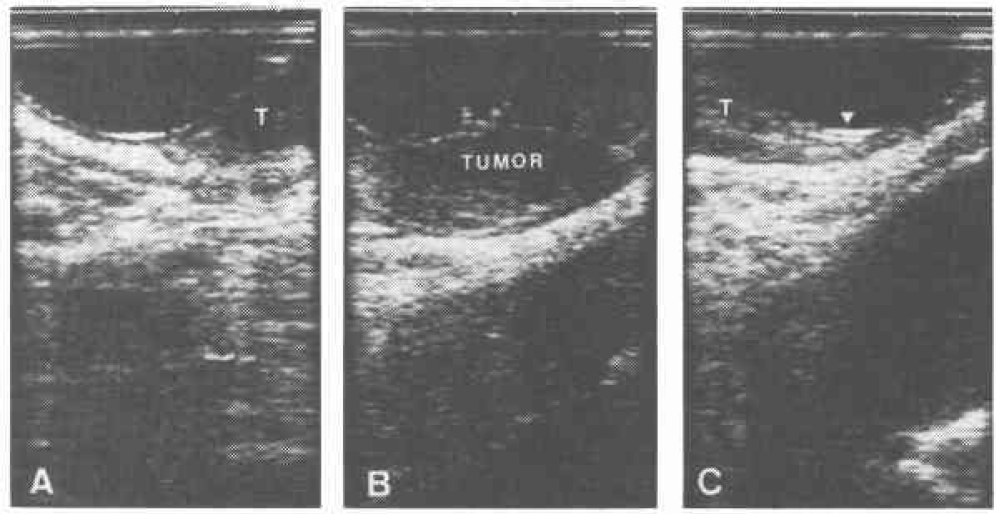
図 6 一症例 1 一切除標本, 口側の抎大像

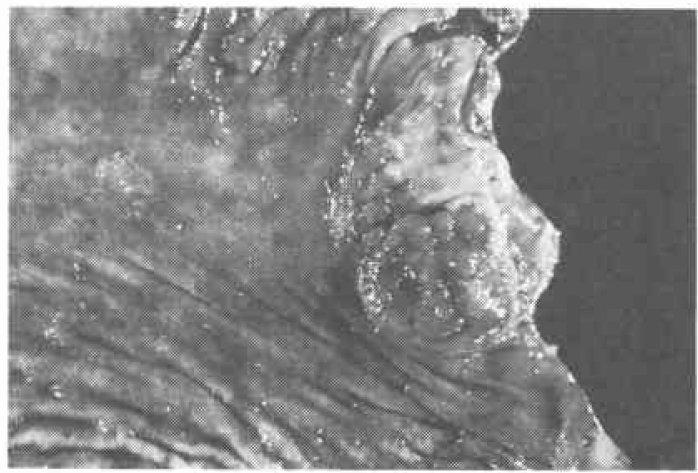

図 7 一症例 1 一上: 切除標本の腫瘍口側の水浸下 echo 像, 下：同部位の組織像 $(\mathrm{HE}$ 染色, $\times 4$ ), 腫湯口側端
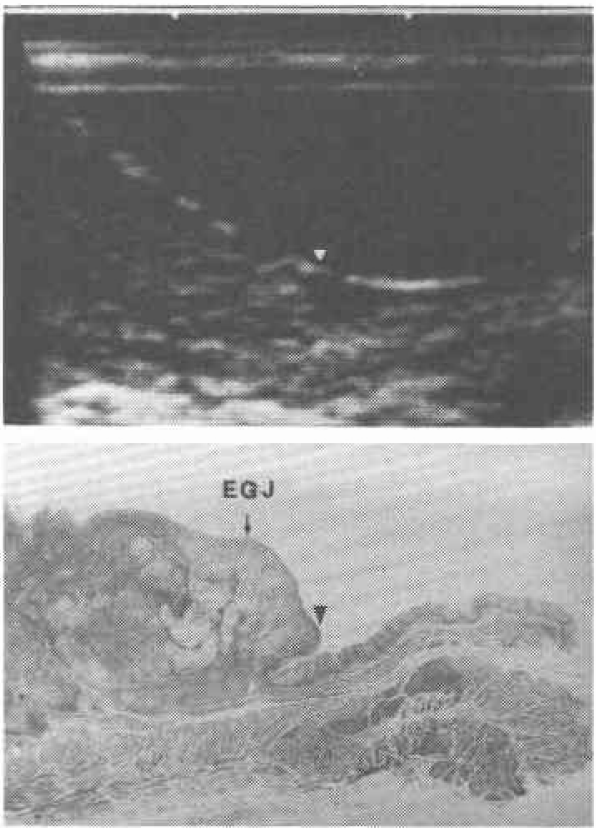

えて EUS 像を示したものが図11である.

いずれも EGJ は描出できなかったが，癌口側端は hiatus 直上から, hiatus の口側 $4.5 \mathrm{~cm}$ の間に描出され た. 7 例之も開腹に加えて, 開胸操作をもって切除可 能であったのが特徴であり，5例は左開胸， 2 例は右 開胸が施行された。図11-1は, 術前 EUSで EGJ は不 明瞭, hiatusまで口側浸潤を認め, 左開胸で手術が施 行された症例である.切除標本で $5 \mathrm{~mm}$ 程食道浸潤が認 められた。しかし，組織学的にはこの約 $1.5 \mathrm{~cm}$ 口側の
図 8 一症例 2一左：MCA 領域におよぶBorr. 4型 胃癌の X 線像, 右：内視鏡像, 噴門部よりの見おろ し像
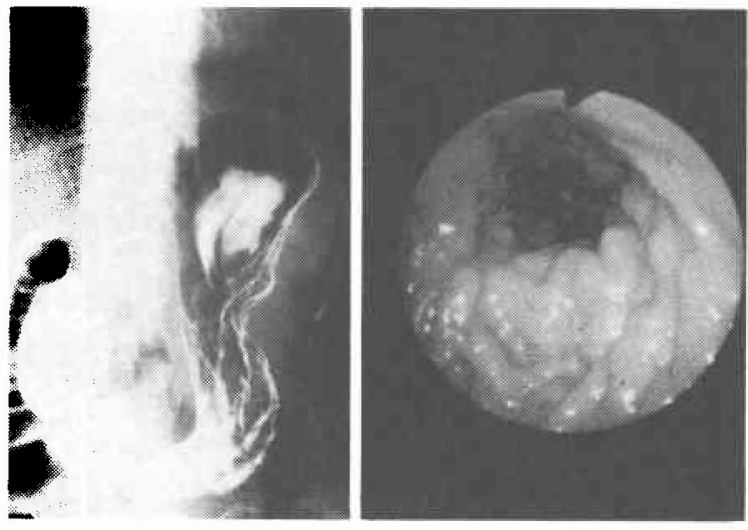

図 9 一症例 2一術前 EUS 像. A : 腫瘍中央部, B 尰瘍口側, $\boldsymbol{\nabla}:$ 腫瘍口側端
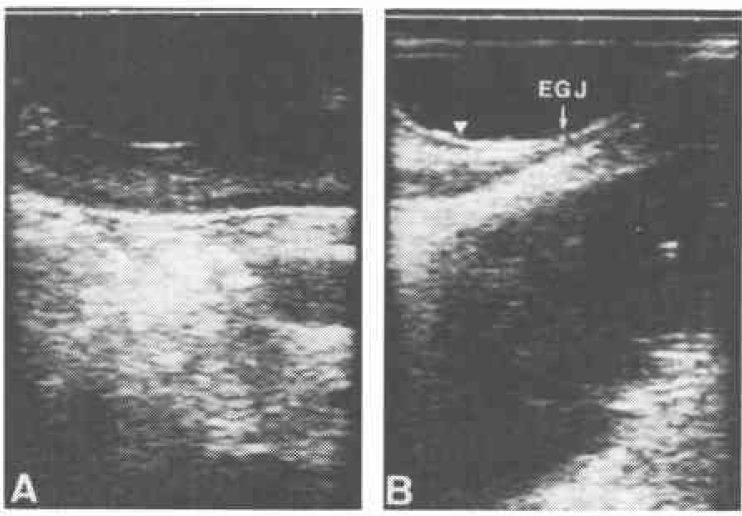

sm 層に壁内転移があり，ow(十)であった。この他の 6 例は2.0〜 $4.8 \mathrm{~cm}$ の owをもって切除されていた。 症例を呈示する。

症例 3 : (図11-No.5 5症例)

64歳男性で，残胃に発生した Borr. 4 型胃癌の症例 である. 2 年前, 胃癌にて胃切除術 (Billroth I 法)を 施行している。 X 線像で残胃は伸展不良, 筒状に変化 していた，裂孔へルニアがあり，EGJおよび癌口側浸 潤の判定は難しかった(図12左)：内視鏡では，食道か らの見括ろしで，閒雬列から $44 \mathrm{~cm}$ まで全周性に伸展 不良で肥厚した粘膜が物よんでいた(図12右上)。少し scope を進めると, 赤色調で易出血性な変化が全周に 認められ，EGJは不明であった（図12右下）.

図13A は噴門部の術前 EUS 像で，残胃は全層にわ 
図10一症例 2-A：切除標本, 腫瘍口側の水浸下 echo 像, $\nabla$ : 腫瘍口側端. B：同部位の組織像 ( HE 染色, $\times 5$ ), 、まで全層性の癌浸潤を認めた.
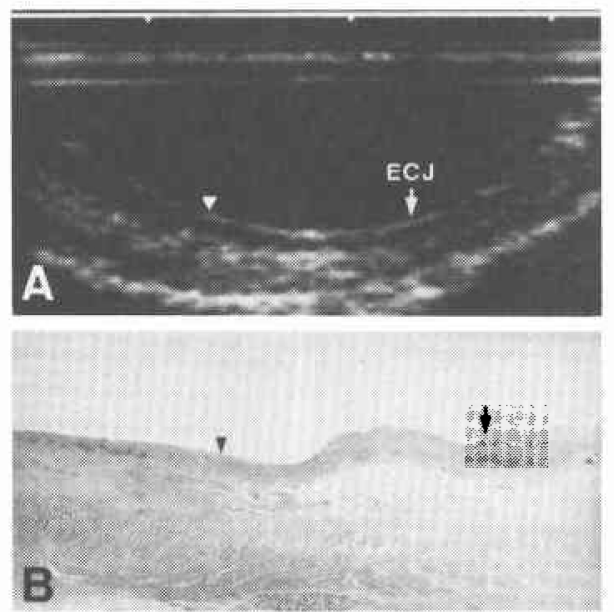

図11 噴門癌の術前 EUS 像一癌口側端が hiatus を越 完る例一

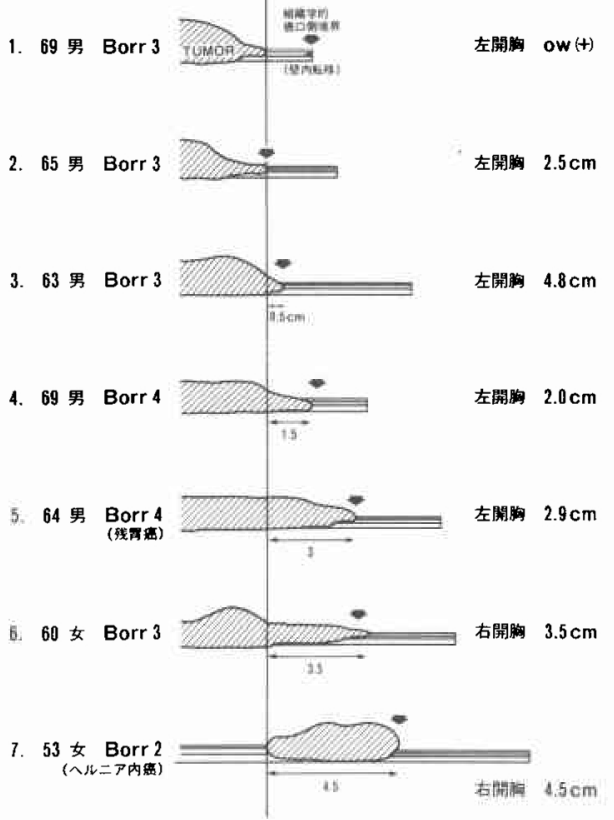

たって肥厚した低 echo 像として描出され，肥厚した 壁は hiatus を越えて胸腔内へと連続していた. 肥厚し た tumor 像は, scope の引き抜き操作で hiatus 上 $3 \mathrm{~cm}$ まで認められた（図13B 矢印）。

腫瘍と膵臓とは接するものの，積極的な漫潤を示す
図12一症例 3一左：Borr.4型残胃癌のX 線像, 右：内視鏡像

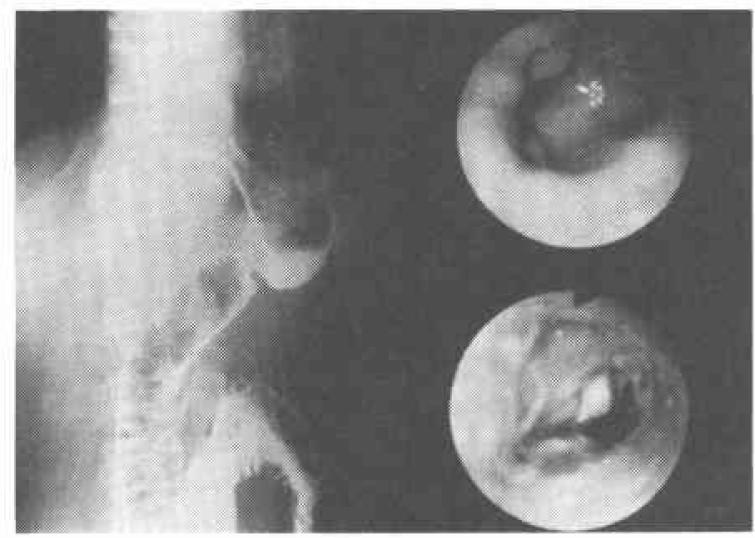

図13 一症例 3一術前 EUS 像, 矢印は腫瘍口側端を 示す
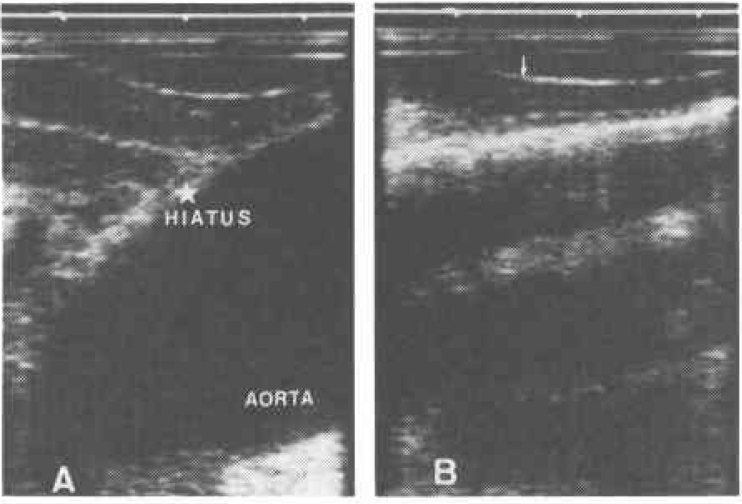

所見は得られなかったが，膵上縁に $25 \mathrm{~mm}$ 大の 8 番リ ンパ節を認めた。一方，小弯側で腫瘍は肝左葉外側区 域と境界不明瞭な部分があり(図14A 矢印)，肝直接浸 潤が疑われた。図14B は開腹時の術中写真で, 肝左葉 外側区域に直接浸潤があり，正診であった。膵脾とと もに肝左葉外側区域合併切除が施行され，左開胸で腫 瘍を摘出した。

切除標本でも EGJ は不明瞭であったが, 腫瘍口側の 水浸下 echo 像は図15上に示すように，三角印の部ま で全層性に肥厚し低 echo 化した腫瘍像が得られた。 図15下はその組織像で，三角印まで全層に浸潤した腫 瘍が認められ，その形態は標本 echo と一致するるの であった，深達度は sei liver, ow $2.9 \mathrm{~cm}$ であった。

症例 4：(図11-No.7の症例)

53歳，女性であるが，X 線像では一見 $\mathrm{Ei}, \mathrm{Ea}$ 食道癌 
図14一症例 3-A：腫瘍中央部の術前 EUS 像. 肝左 葉外側区域直接漫潤と診断した (矢印)，B：術中写 真. 矢印部で肝左葉外側区域直接浸潤を認めた。
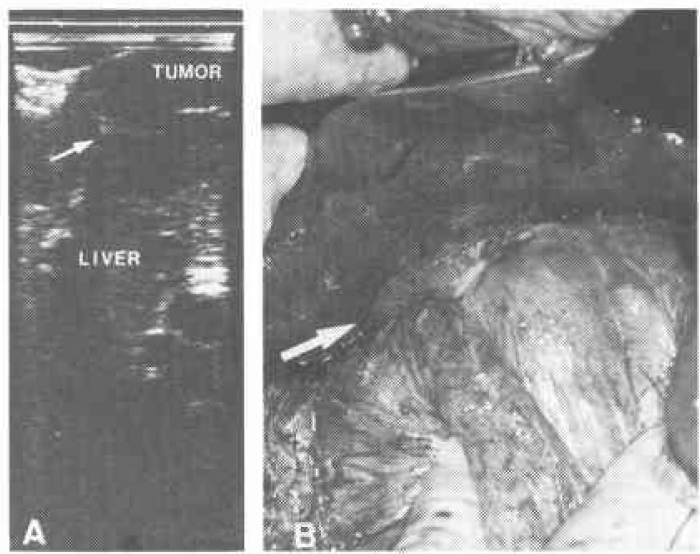

図15一症例 3一上：切除標本口側の水浸下 echo 像, 下：同部位の組織像 $(\mathrm{HE}$ 染色 $\times 5), \boldsymbol{\nabla}$ : 腫瘍 口側端
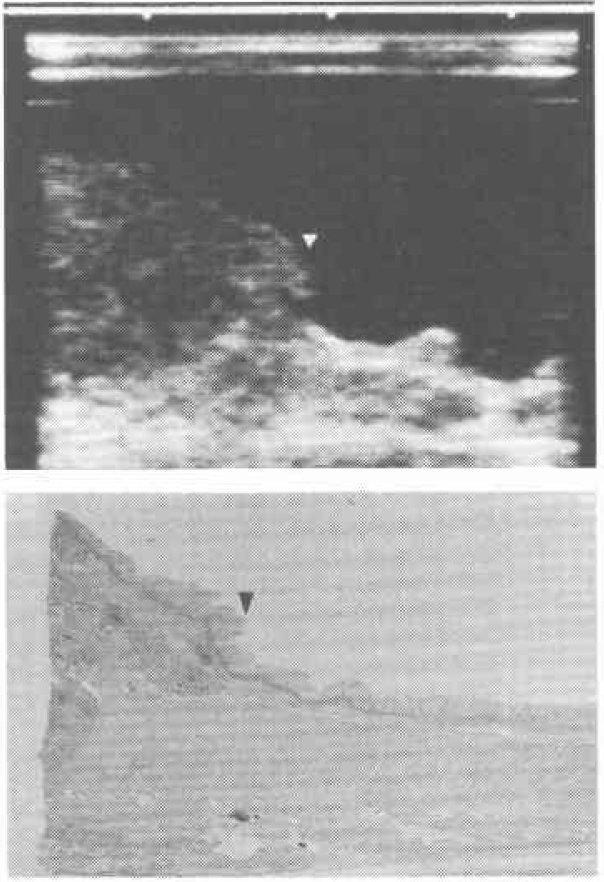

を思わせるように，下部食道に陰影欠損を認めた（図 16左).内視鏡で図16右上は口側よりの見和ろし像, 右 下は cardia 反転像であるが, hiatus hernia があり, 腫 瘍肛門側は hiatus 内に入り込むように存在しており，
図16一症例 4 一左：X線像, 右上：内視鏡像, 食道 側よりの見おろし像，右下：内視鏡像, 胃内反転像
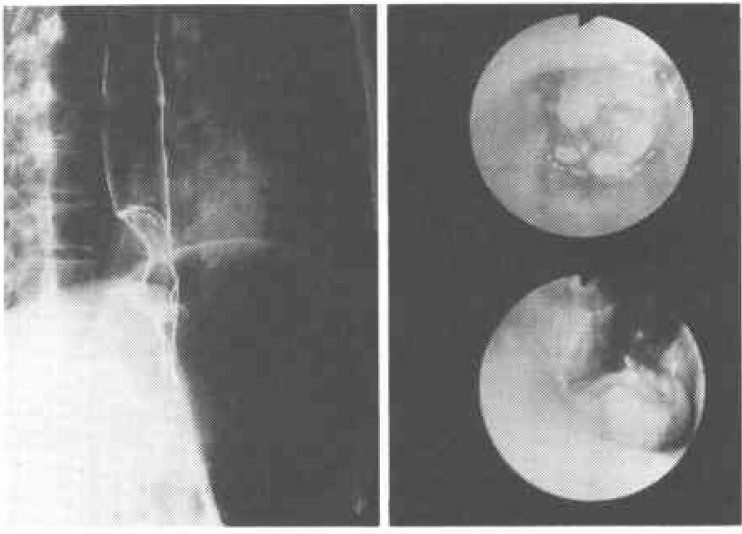

EGJ は不明瞭であった. biopsyでは adeno carcinomaであった。

術前 EUS 像では，図17A に示すように，m, sm 層 の肥厚として描出される腫瘍肛門側端（三角印）は hiatus (星印) 直上に認められた。B は畽瘍中央部を示 したもので, sm 層は断裂し，pm 層まで含めて低 echo 化した腫瘍塊を形成しており，一部第 5 層の不整もあ り $\mathrm{S} 1$ と診断した。Cは腫瘍口側端で，境界明瞭に描出 され hiatus 上 $4.5 \mathrm{~cm}$ に位置していた。

また，図19A に示すよらに，腫瘍に接して $2 \mathrm{~cm}$ 大の 110番リンパ節を描出して和り，この他緃隔内107番, 108番にも $1 \mathrm{~cm}$ 大のリンパ節を認めたため，手術は右 開胸, 開腹で行われ, 胸腔内リンパ節郭清も施行され た。

図18は切除標本で，EGJにだる4.5×3.5cmの Borr. 2型の胃癌であった。

図19B は110番のリンパ節の切除標本の水浸下 echo 像，Cはその組織像で，転移陽性であり正診されてい た.

図20上は腫瘍口側端の標本 echo 像, 下は組織像で, 良く一致した像が得られた。組織学的に深達度は pm で, 術前 EUS ではバルーンの押しつけにより, 深達度

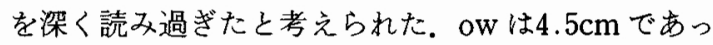
た.

\section{5. 考 察}

超音波内視鏡診断の試みは, 久永ら拉よび DiMagno $^{9}$ の報告に始まり，胃疾患，食道疾患の診断入 と導入された。すず，胃壁が 5 層構造として描出され ることが報告され ${ }^{10)}$ ，その後も詳しい胃壁の層構造の 


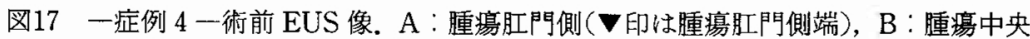
部, C : 腫瘍口側端 ( $\boldsymbol{\nabla}$ 印), $\mathrm{T}$ : tumor
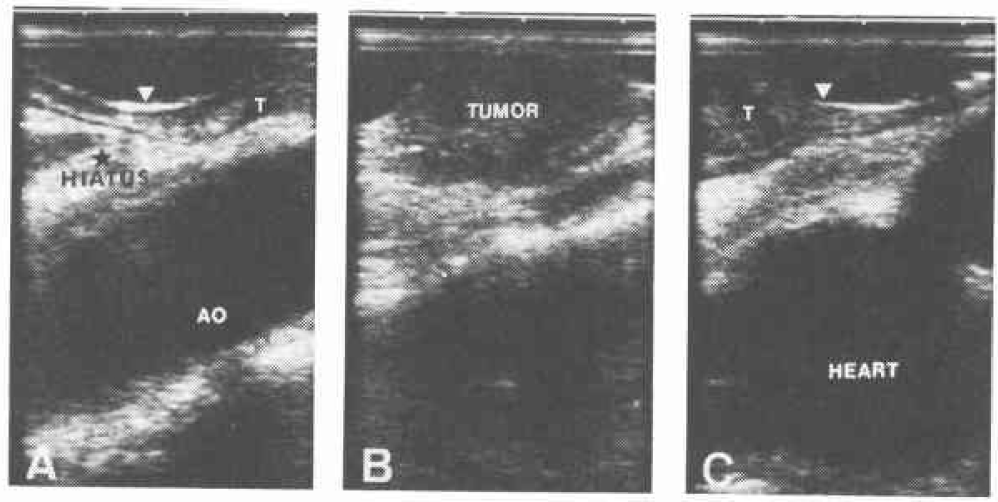

図18 一症例 4 一切除標本

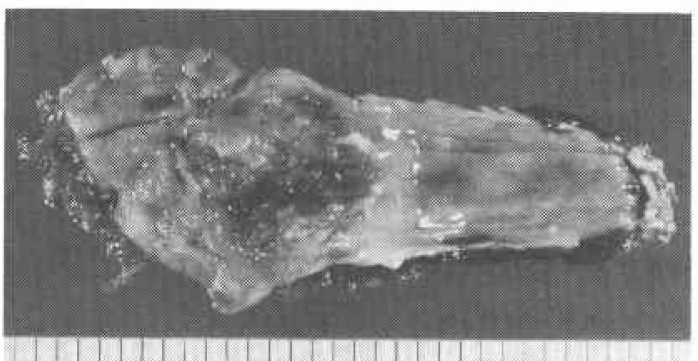

図19 一症例 4-A：術前 EUS 像, 腫瘍に接して110

番リンパ節を描出した, B：同部位の切除標本の水 浸下 echo 像, C：組織像 (HE 染色, $\times 2$ )
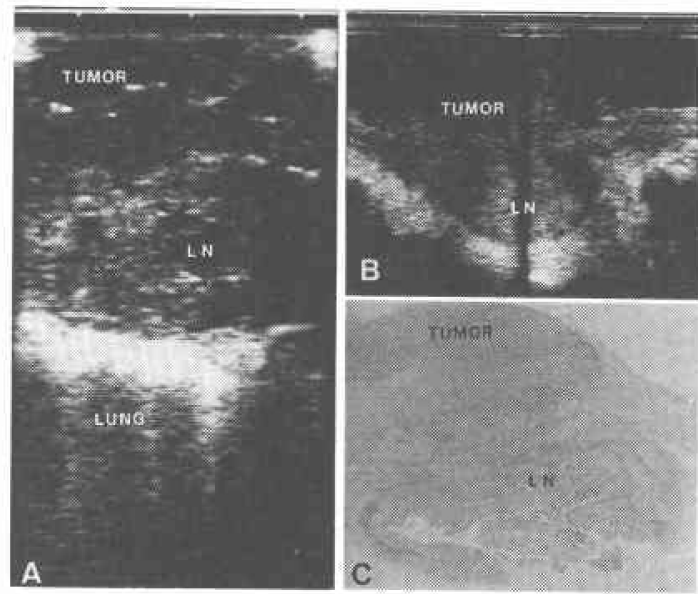

図20一症例 4 -上: 切除標本口側の水浸下 echo 像,下：同部位の組織像 ( $\mathrm{HE}$ 染色, $\times 4$ )
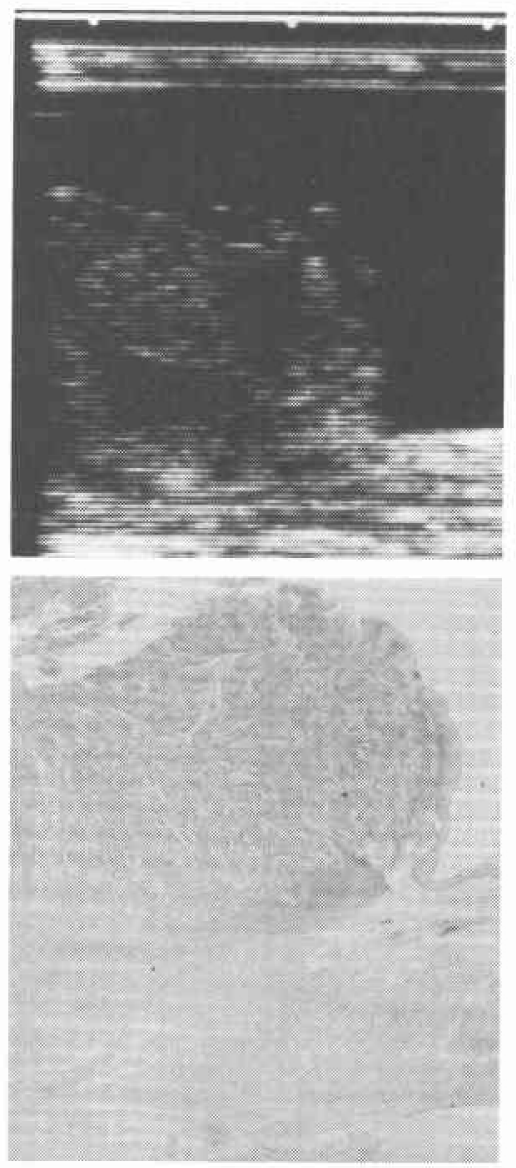
組織学的解明がなされてきた ${ }^{11)}$

われわれも1981年 6 月より,リニア型 EUS の上部 消化管疾患に打ける有用性を検討してきた ${ }^{12113)}$ が，切 除標本を用いた基礎的検討では，正常食道壁は基本的 に 7 層構造を示すが, 通常は 5 層, 3 層で描出される ことが多く，胃壁と比較して薄く描出されることを報 告している ${ }^{14)}$.さらに，現在使用している周波数 7.5 $\mathrm{MHz}$ のリニア型 EUS では, 臨床例に乱いて胃壁は通 常 7 層として描出され，食道壁でも条件が良い場合は 7 層構造に描出可能となっている。また、リ二ア型 EUSでは，下部食道から噴門部に対し縦軸方向にプ ローブがあたるため, 食道から胃への層構造の変化を, 同一画面で連続的に観察することが可能である，そこ で今回, 食道胃境界領域の層構造の変化について検討 した.

切除標本を用いて，EGJ 下での層構造の变化を観察 したところ, EGJ を境に胃側では sm 層, $\mathrm{pm}$ 層とも厚 くなる例が多いことがわかり, 組織学的にも確認寸る ことができた。臨床的には, hyperechoicな sm 層が肥 厚, 明瞭化する点を $\mathrm{EGJ}$ の目安にできると考えられ た.

次に，噴門部後壁の走查で胃壁と大動脈との間に hypoechoic な横隔膜筋脚が描出されることに着目し, この口側先端を横隔膜筋脚が横隔膜に移行する部，す なわち hiatus と同定した。通常の症例では EUS 画像 上EGJ は hiatus 直下から hiatus 下約 $2 \mathrm{~cm} の$ 範囲内 に描出された. hiatus hernia の症例では EGJ が hiatusを越えて胸腔内に入り込んでいる像が得られ, EUS 上も hiatus herniaを確認することができた. EUS 画像上の横隔膜筋脚の口側先端は, 臨床的に胸 腔，腹腔の境界を示しており，hiatusに一致するもの であると考えられる。

この EGJと hiatusの同定法を応用し，リニア型 EUS による上部胃癌, 特に噴門癌とその食道浸潤例の口側 浸潤診断を試みた。

噴門癌の手術に際してまず問題になるのは，開胸操 作が必要か否かという点であり, 術前診断で口側進展 のあるものは, 十分な切除, 郭清, 安全な吻合のため に開胸操作が必要となる。従来, 噴門癌の口側浸潤診 断は，X 線，内視鏡で行われてきたが，X 線診断的に は, 写真上, 食道浸潤の上限が横隔膜の頂上を越える ものは必ず開胸操作を要するといら䛦断方法 ${ }^{15}$ は良く 知られている。最近では，X 線的に食道浸潤が $1 \mathrm{~cm}$ 以 上あれば積極的に開胸するという報告 ${ }^{16)}$ 白見られる.
しかし, 進行癌では EGJ の決定が困難な場合も見ら れ，また，最近多く見られる残胃癌の診断に際してる， 裂孔へルニアを合併していたり，二重造影が難しい場 合もあり，口側浸潤診断は難しい。内視鏡的には, 噴 門癌の食道進展様式は粘膜下先進型, 筋層内先進型が 多いこと年を考えると, 粘膜面の変化を読む内視鏡診 断にる限界があると考えられる。

これらの問題点から考えて, EUSによる噴門癌の深 達度診断, 口側浸潤診断は非常に期待されるすのであ ク,リニア型EUS の特性を発揮できる領域であると 考学らるる181199.

EUS 上腫晹と EGJ, また, 今回設定した hiatus との 位置関係を描出し, 摘出標本との比較を行ったが, 術 前 EUS でEGJ が確認できた例では摘出標本です EGJ を基準として対比することができた. $\mathrm{X}$ 線, 内視 鏡診断の難しいBorr. 4 型胃癌, 残胃癌を含め良好な 結果を得た。

しかし，EGJの描出が不能であった食道浸潤例では hiatus の位置関係が摘出標本で確認できないため, 正 確な標本との対比は難しくなる。 そこで, 腫瘍口側端 の像について, 術前 EUS と標本 echo, 組織像との対 比を行った。食道浸潤を伴うような胃癌は当然進行癌 が多く, Borr. 3型, Borr. 4型といった浸潤癌が多く見 られたが, 標本上層構造に変化をきたしている場合, 忠実に EUS 像の変化として描出可能であった。誤診 の原因は balloonの押し付けによる読み過ぎ, 食道浸 潤の長さを計測する際に scope の引き抜き操作括よ び回転操作をするための誤差によると考光られた。

また, EUSによる癌深達度診断では microscopic な レベルまでの診断は困難であるのは当然のことである が，口側浸潤診断に和いても同様の結果であった。つ まり, EUSは切除標本の割面のルーべ像を見ることの できる術前検査法という印象を受けた。

このように検討してきた胃癌口側端の EUS 像につ いて, hiatusを基準にして検討を試みた. EUS 画像上, 腫瘍口側端が hiatusを越えないもの, 越劣るものとで 分類したところ, 実際施行された術式にも差が認めら れた。癌口側端が hiatus を越えなかった症例は, 経腹 的操作のみで ow $1.1 \sim 2.5 \mathrm{~cm}$ をって切除可能で あったのに対し，hiatusを越えていた症例はいずれる 経腹的操作に加えて開胸操作を必要とした。われわれ が設定した hiatus は消化管壁外の構造物であり, 癌浸 潤の程度にかかわらず描出可能であるため, 癌口側浸 潤において普遍的な基準になりらると考えられた。 
今後は, 術前 EUS で hiatus と描出した位置や, 癌口 側端に clip などで marking し，標本上での hiatusの 位置を検討したいと考穴ているが，現在使用中の機種 には鉗子孔がなく，機種の改良が望まれるところであ る.

また，今回は腫煌口側端の形態を分類するまでには 至らなかったので, 今後症例を重㱛て検討したいと考 えている。

\section{6. 結 論}

1）リニア型EUSを用いて，EGJおよび hiatus の 描出法を明らかにした。

2) EGJ, hiatus の同定法を応用し，上部胃癌，特に 噴門癌とその食道浸潤例の口側浸潤診断を行った。

3）EUS 画像上, 癌口側端が hiatusを越えないむ の, 越えるものとで分類したところ, 実際施行された 術式にも差が認められた. EUS 上の hiatus と腫瘍の 位置関係から術式を検討すべきと考兄られた。

$$
\text { 文献 }
$$

1）荻野幸伸，神津照雄，円山正博注か：リニア型電子 走查式超音波内視鏡（4号機）の検討. Gastroenterol Endosc $25: 1374-1381,1983$

2）相部 剛, 大谷達夫, 吉田智治㳗か：超音波内視鏡 による胃癌深達度診断. 胃と腸 $19 ： 1299-1304$, 1984

3）安田健治朗, 清田啓介, 向井秀一保加：内視鏡的超 音波断層法（EUS）による上部消化管病变の診断 一胃癌深達度診断を中心に一. Gastroenterol Endosc $28: 253-263,1986$

4）芳野純治, 中澤三郎, 太田博郷ほか：超音波内視鏡 によるスキルス型胃癌診断. Gastroenterol Endosc 28 : 1546-1552, 1986

5) 伊藤忠彦, 相部 剛, 吉田智治ほか：超音波内視鏡 による食道癌の深達度診断およびリンパ節転移の 検討. Gastroenterol Endosc 28 : 1193-1201, 1986

6）大島郁也，神津照雄：消化管癌の内視鏡的治療 一胃癌に打忛る超音波内視鏡の利用について一。
Gastroenterol Endosc 29 : 1307-1308, 1987

7) Collis JL, Kelly TD, Wiley AM : Anatomy of the crura of the diaphragm and the surgery of hiatus hernia. Thorax $9: 175-189,1954$

8) Hisangaga $K$, Hisanaga A: A new real time sector scanning system of ultra-wide angle and real time recording of entire adult cardiac image-Transesophagus and trans-chest-wall methods-. Edited by White DN, Lyons EA. Ultrasound in Medicine. Vol 4. Plenum Press, New York, 1978, p391-402

9) DiMagno EP, Buxton JL, Regan PT et al: Ultrasonic Endoscope. Lancet 1 : 629-631, 1980

10）相部 剛, 富士 匡, 浅上文雄ほか：超音波内視鏡 の検討(第 2 報). Gastroenterol Endosc 24：1900 $-1909,1982$

11）相部 剛：超音波内視鏡による消化管壁の層構達 に関する基礎的, 臨休的研究 (1) 胃壁の㬝構造に ついて. Gastroenterol Endosc 26:1447-1464, 1984

12）荻野幸伸：リ二ア型超音波内視鏡による食道疾患 診断の研究. Gastroenterol Endosc $27: 3-14$, 1985

13）神津照雄：超音波内視鏡検查. Gastroenterol Endosc $28: 2901-2908,1986$

14）荻野幸伸, 神津照雄, 円山正博注か：食道癌におけ るリニア電子走查式超音波内視鏡の試み. Gastroenterol Endosc $25: 1688-1696,1983$

15）遠藤光夫：食道, 噴門部癌の外科 2 , 内視鏡診断の 立場から。臨外医会誌 $40: 863-868,1979$

16）高木國夫：食道, 噴門部癌の外科 $2, \mathrm{X}$ 線的立場か 5. 日臨外医会誌 $40: 860-863,1979$

17）西 满正, 野村秀洋, 加治佐隆注加: 食道・胃境界 領域癌の外科的治療の問題点. 胃々腸 $13: 1497$ $-1507,1978$

18）吉田行雄, 山中桓夫：超音波内視鏡の胃癌深達度 診断能の問題点. Gastroenterol Endosc $27: 834$ $-836,1985$

19）神津照雄, 荻野幸伸, 磯野可一：食道癌の超音波内 視鏡診断。癌の臨 $32: 1131-1135 ， 1986$ 